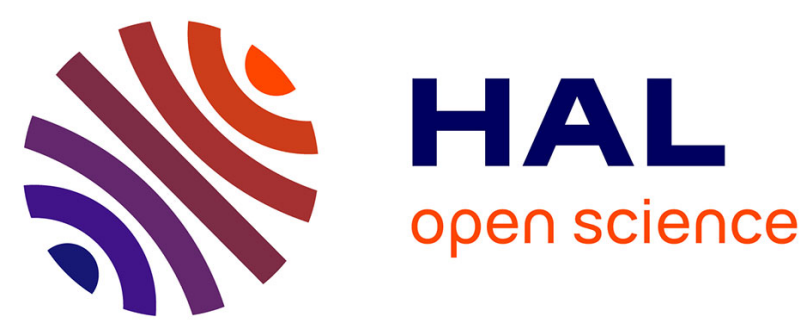

\title{
Effect of prochloraz fungicide on biotransformation enzymes and oxidative stress parameters in three-spined stickleback (Gasterosteus aculeatus L.)
}

Wilfried Sanchez, Benjamin Piccini, Jean-Marc Porcher

\section{- To cite this version:}

Wilfried Sanchez, Benjamin Piccini, Jean-Marc Porcher. Effect of prochloraz fungicide on biotransformation enzymes and oxidative stress parameters in three-spined stickleback (Gasterosteus aculeatus L.). Journal of Environmental Science and Health, Part B, 2008, 43 (1), pp.65-70. 10.1080/03601230701735151 . ineris-00961921

HAL Id: ineris-00961921

https://hal-ineris.archives-ouvertes.fr/ineris-00961921

Submitted on 20 Mar 2014

HAL is a multi-disciplinary open access archive for the deposit and dissemination of scientific research documents, whether they are published or not. The documents may come from teaching and research institutions in France or abroad, or from public or private research centers.
L'archive ouverte pluridisciplinaire HAL, est destinée au dépôt et à la diffusion de documents scientifiques de niveau recherche, publiés ou non, émanant des établissements d'enseignement et de recherche français ou étrangers, des laboratoires publics ou privés. 


\title{
Effect of prochloraz fungicide on biotransformation enzymes and oxidative stress parameters in three-spined stickleback (Gasterosteus aculeatus L.)
}

\author{
WILFRIED SANCHEZ*, BENJAMIN PICCINI and JEAN-MARC PORCHER \\ Unité d'évaluation des risques écotoxicologiques, Institut National de l'Environnement \\ Industriel et des Risques (INERIS), Verneuil en Halatte, France
}

\begin{abstract}
The aim of this study was to characterise biomarker responses in three-spined sticklebacks exposed to prochloraz (Pcz). For this purpose, adult sticklebacks were exposed for 2 weeks to prochloraz at $0,10,50,100$ and $500 \mu \mathrm{g} / \mathrm{L}$ prior to one week of depuration in clean water. At days 7, 14 and 21, several hepatic biomarkers were measured including 7-ethoxyresorufin-Odeethylase (EROD), glutathione-S-transferase (GST), glutathione peroxidase (GPx), catalase (CAT), total glutathione (GSH) content and thiobarbituric acid reactive substances (TBARS). Pcz induced a transient increase of antioxidant enzymes and a depletion of glutathione content during the first 7 days of exposure. This study showed that EROD activity and antioxidants were disrupted in a transient manner. GST was rapidly induced in a dose-dependent manner and this induction was persitent and observed also after depuration. GST appeared as a valuable biomarker to assess the exposure to Pcz.
\end{abstract}

* Address correspondence to Wilfried Sanchez, Institut National de 1'Environnement Industriel et des Risques (INERIS), Unité d'évaluation des risques écotoxicologiques, Verneuil en Halatte, France ; Phone : +33 (0)3 446181 21, Fax: +33 (0)3 $44556767^{\circ}$; Email : Wilfried.Sanchez@ineris.fr 
Keywords : biomarkers, biotransformation enzymes, liver, oxidative stress, prochloraz, threespined stickleback

\section{INTRODUCTION}

Azole fungicides play a key role as antifungals and are widely used in agriculture around the world. Among these compounds, the imidazole Pcz (N-propyl-N-(2-(2,4,6-trichlorophenoxy)ethyl)imidazole-1-carboxamide) is a broad-spectrum contact fungicide employed in Europe, South America, Asia and Australia, against several diseases in wheat, barley and oleaginous plants but also for the treatment of flower production and of turf on golf courses.

As with other imidazole compounds, the action of Pcz is based on the unspecific strong interaction with the iron atom of cytochrome P450. This binding inhibits the cytochrome P450-dependent 14 $\alpha$-demethylase activity required in the conversion of lanosterol to ergosterol, an essential component of fungal biological membranes, and disturbs the cell membrane assembly. ${ }^{[1]}$

Agricultural application of Pcz contributes to the diffuse freshwater pollution in several European countries including France and the United-Kingdom. ${ }^{[2,3]}$ In several rivers of Northern France, Pcz appears as one of the most quantified pesticides and its measured concentrations in surface waters are 5-fold higher than the official standard value of $0.5 \mu \mathrm{g}$ of pesticides/L. ${ }^{[2]}$

In freshwater ecosystems, Pcz can generate adverse effects to aquatic organisms. Pcz LC50 values for rainbow trout, harlequin fish and bluegill sunfish are in the range 1.5-2.90 $\mathrm{mg} / \mathrm{L}$. [4] As in fungi, Pcz modulates fish cytochrome P450 enzyme activities. Pcz is able to modulate the rainbow trout CYP1A system involved in organic pollutant detoxification 
process, inducing both inhibitory and induction effects on CYP1A expression and EROD activity. ${ }^{[5,6]}$ A recent study reported inhibition of CYP19 aromatase activity, an enzyme involved in steroid metabolism, in the brain of male and female fathead minnow. ${ }^{[7]}$ In rainbow trout, Pcz can also modulate the phase II biotransformation enzymatic activities such as GST ${ }^{[5]}$, a well known enzyme involved in protection against oxidative stress. ${ }^{[8]}$

Pcz is a fungicide widely encountered in European freshwater ecosystem and can generate adverse effects in fish. However, to our knowledge, no study has investigated the early effect of Pcz on the biomarker responses in stickleback. This study was conducted to assess the biochemical responses in Pcz-exposed three-spined stickleback (Gasterosteus aculeatus L.) using biotransformation enzymes (EROD and GST) and oxidative stress parameters such as GPx, CAT and GSH content, as well as TBARS content (for review, see Van der Oost et al. $\left.{ }^{[9]}\right)$. Stickleback has been used as a model organism to study biochemical responses to various xenobiotics such as metals ${ }^{[10]}$, pesticides ${ }^{[11,12]}$, halogenated organic compounds ${ }^{[13]}$ or environmental estrogens and androgens. ${ }^{[14,15]}$ More recently, stickleback has been described as a valuable sentinel fish species to assess sublethal stress in multipollution context. ${ }^{[16]}$ Among the investigated parameters, EROD is a well documented biomarker in fish but its sensitivity and inducibility in stickleback are not described. Hence, the kinetic of EROD activity was first performed by using $\beta$-naphtoflavone (BNF) as a reference inducing compound for this enzyme.

MATERIALS AND METHODS

Fish Maintenance and Exposure 
Male and female adult sticklebacks were collected in uncontaminated outdoor artificial streams (INERIS, France) and maintained in experimental water (alkalinity, $367 \mathrm{mg} . \mathrm{L}^{-1}$ as $\left.\mathrm{CaCO}_{3} ; \mathrm{pH}, 8.35 \pm 0.05\right)$ for 2 weeks prior to experimentation. The water temperature was $13.5^{\circ} \mathrm{C} \pm 1{ }^{\circ} \mathrm{C}$ and the photoperiod was a light/dark cycle of $8 / 16$ hours. Fish were fed every other day with frozen red mosquito larvae.

Fish were randomly distributed in 15 litres tanks and waterborne exposed to Pcz under semistatic conditions with complete water renewal and food supply every other day.

\section{$\beta$-naphtoflavone exposure}

BNF was dissolved in $5 \mathrm{~mL}$ of dimethyl sulphoxide (DMSO) and added to the experimental water with a maximal final concentration below $0.0001 \%$. Fish $(n=240)$ were exposed to 0.3, 0.9 and $2.7 \mu \mathrm{M}$ for $12,24,48,72$ and 96 hours. In this experiment, one fish group was sampled before contamination as an initial control $(0 \mathrm{~h})$. Moreover, a control group was performed for each exposure time with and without solvent. At each sampling time, 10 fish per tested concentration were randomly collected for biochemical analysis.

\section{Prochloraz exposure}

Pcz was previously dissolved in $1 \mathrm{~mL}$ of absolute ethanol and added to the experimental tank water with a maximal solvant final concentration of $0.0001 \%$. Fish $(n=160)$ were exposed to 10, 50, 100 and $500 \mu \mathrm{g} / \mathrm{L}$ (i.e. $0.03,0.13,0.3$ and $1.3 \mu \mathrm{M}$ ) for 7 and 14 days. After 14 days, 10 fish per concentration were submitted to a depuration experiment and were maintained in uncontaminated water for 7 days with the same experimental conditions. In this experiment, 
an initial control $(0 \mathrm{~h})$ and controls for each exposure length (7, 14 days and 7 days of depuration) were performed. At each sampling time, 10 fish per tested concentration were randomly collected for biochemical analysis.

\section{Biochemical Analysis}

Fish were sacrificed, measured and weighed. Liver was dissected, weighed and homogenized in ice-cold phosphate buffer (100 mM, pH 7.8) supplemented with $20 \% \mathrm{v} / \mathrm{v}$ glycerol and 0.2 $\mathrm{mM}$ phenylmethylsulfonyl fluoride as a protease inhibitor. The homogenate was centrifuged at $10,000 \times \mathrm{g}, 4^{\circ} \mathrm{C}$, for $15 \mathrm{~min}$ and the supernatant was used for biochemical assays after measurement of total protein concentration using the method developed by Bradford et al. ${ }^{[17]}$. All biochemical assays (EROD, GST, GPx, CAT, GSH and TBARS) were carried out as previously described by Sanchez et al. ${ }^{[10,16]}$

\section{Statistical Analysis}

All data are reported as mean \pm standard deviation obtained from the data of individual fish randomly sampled. SPSS 13.0 software was used for statistical analysis. Normal distribution and homoscedasticity of data were verified using respectively Kolmogorov-Smirnov and Levene tests. When data sets didn't have a normal distribution and/or homogeneity of variance, the biomarker data were $\log$-transformed, using $\mathrm{F}(\mathrm{x})=\log (1+\mathrm{x})$, prior to parametric analysis. Differences between biomarker responses in control of male and female fish were searched using a t-test. If a significant difference $(\alpha=0.05)$ was observed, male and female data were treated separately. A two-way analysis of variance, using time and concentration of exposure, was performed to assess the difference of evaluated parameters for all experimental 
conditions. When the null hypothesis was rejected $(\alpha=0.05)$, the position of significant difference with the control group were tested using Sidak post hoc test $(\alpha=0.05)$.

\section{RESULTS AND DISCUSSION}

\section{Sensitivity of EROD Induction in Stickleback}

BNF exposure allows determination of a dose-response curve and completes the previous works showing the inductibility of stickleback EROD activty by chemicals in laboratory ${ }^{[13,18]}$ and field experiments. ${ }^{[16]}$ During this exposure no significant difference between male and female stickleback EROD activities was noticed. After 12 hours of BNF exposure, an increase of EROD activity was measured for each tested concentration (Fig. 1). This induction was also observed for all exposure times and appeared as dose-dependent after 48, 72 and 96 hours. Maximal inductions of 7,15 and 18 fold were observed after 72 hours (Fig.1).. The induction factors measured in the BNF exposure were similar to factors reported in fish species widely used in European field studies such as chub and gudgeon ${ }^{[19]}$ but stickleback EROD appears less inducible than in rainbow trout, a fish species more widely used in laboratory for ecotoxicological studies. ${ }^{[20]}$

\section{Effect of Pcz on Sticleback Biomarker Responses}

Results obtained for EROD activity are presented in Figure 2A. A transient 3- and 7-fold EROD induction was measured after 7 days of exposure to 50 and $100 \mu \mathrm{g} / \mathrm{L}$ respectively. A significant EROD induction was also reported after prochloraz exposure to $500 \mu \mathrm{g} / \mathrm{L}$ for 7 and 14 days with an induction factor of 7 and 5 fold respectively. After 7 days of depuration, no 
significant difference was observed between exposed and unexposed groups (Fig.2A). The present study shows that Pcz fungicide is able to induce EROD activity in three-spined stickleback. This induction appears as dose-dependent and moderate compared to the results obtained using a typical EROD inducer such as BNF. Scientific literature includes some examples of similar EROD induction generated by Pcz. ${ }^{[5-6]}$ Previous studies reported a transient 3-fold increase of EROD activity in rainbow trout after 7 days of $100 \mu \mathrm{g} / \mathrm{L}$ waterborne exposure ${ }^{[6]}$ and intraperitoneal injection of Pcz. ${ }^{[5]}$ To our knowledge, the mechanism of EROD induction by Pcz is unknown but several studies have investigated the structural and molecular basis of EROD induction by imidazole compounds such as clotrimazole, 1-benzylimidazole and Pcz. ${ }^{[21-23]}$ These molecules present a non-planar conformation inconsistent with the fixation to the aryl hydrocarbon receptor (AhR) and an EROD induction. A possible explanation could be that the imidazoles are converted intracellularly into planar metabolites which then bind as ligands to the AhR. ${ }^{[23]}$ This hypothesis is in accordance with the rapid and extensive metabolisation of the highly lipophilic Pcz fungicide $\left(\log \mathrm{K}_{\mathrm{ow}}=4.12\right)$ to more polar metabolites as suggested by Cravedi et al. ${ }^{[24]}$. In this context, the easier excretion of polar Pcz metabolites could explain the transient response observed for EROD activity.

Results obtained for GST are presented in Figure 2B. After 7 and 14 days of Pcz exposure, GST was increased for the two highest concentrations (i.e. 100 and $500 \mu \mathrm{g} / \mathrm{L}$ ). GST increase was also observed after 14 days of exposure to the lower concentration (i.e. $10 \mu \mathrm{g} / \mathrm{L}$ ). After 7 days of depuration in clean water, a significant induction of GST was noticed for all tested Pcz concentrations (Fig.2B). Phase II biotransformation enzymes such as GST could play an important role in rapid and extensive metabolisation of Pcz. GST is implied in conjugation of electrophilic compounds with endogenous GSH. This reaction increases hydrophilicity of xenobiotics and thereby enhance excretion and consequently gives a detoxification effect. 
This hypothesis is consistent with the observed dose-dependent and persistent induction. Moreover, it is supported by previous studies investigating the effects of herbicides on stickleback hepatic enzymes that reported GST induction by various pesticides such as diquat ${ }^{[12]}$ and fomesafen. ${ }^{[25]}$ However, the response of GST could also be linked to Pcz-induced oxidative stress, since this enzyme is involved in the protection against reactive oxygen species. $^{[26]}$

To our knowledge, no study has investigated the induction of oxidative stress by Pcz and the present results are the first evidence of Pcz-promoted oxidative stress in fish. Results obtained for oxidative stress parameters measured after 7 days of exposure are presented in Table 1. As previously reported, GPx is a gender dependent parameter with a higher activity in female than in male stickleback ${ }^{[16]}$ so, data are presented separately. Three exposed groups (i.e. 50, 100 and $500 \mu \mathrm{g} / \mathrm{L})$ contained only one male fish. Hence, results are not presented and only female data is interpreted. After 7 days of exposure to 100 and $500 \mu \mathrm{g} / \mathrm{L}$, female fish exhibited an inhibition of GPx. This phenomenon could be explained by the suicidal substrate role played by Pcz. A similar mechanism has been reported for other imidazole compounds such as clotrimazole, which is oxidised to a highly reactive free radical before inactivating peroxidase. ${ }^{[27]}$ This inhibition leads to an accumulation of $\mathrm{H}_{2} \mathrm{O}_{2}$ and causes a decrease of GSH content and lipoperoxidation. ${ }^{[27]}$

GPx inhibition was correlated with the decrease of GSH and the increase of CAT in fish exposed to $500 \mu \mathrm{g} / \mathrm{L}$ (Table 1) suggesting that high Pcz concentrations promote oxidative stress. The responses of enzymatic and non-enzymatic antioxidants appeared as transient while no significant variation was observed after 14 days of exposure and 7 days of depuration (data not shown). Moreover, no significant variation of TBARS content was noticed (Table 1) showing that no oxidative damages occurred. This decrease of GSH could be linked to the inhibition of GPx, but also to the increase of GST activity that used reduced 
GSH. Besides, an inhibitory effect on GSH regenerating systems (e.g. GSH reductase and/or GSH synthetase), which was not assessed in our study, might contribute also to the observed depletion of total GSH. Indeed, in a recent study, Knorpp et al. ${ }^{[28]}$ showed that catalytic activity of GSH synthetase is diminished by $\mathrm{H}_{2} \mathrm{O}_{2}$ and pointed out the sensitivity of this enzyme to oxidative stress and the protective role of peroxidase. Hence, in the present work, Pcz could inhibit GSH synthetase activity following $\mathrm{H}_{2} \mathrm{O}_{2}$ production and accumulation. The fact that we did not observe lipid peroxidation generated by Pcz indicates that antioxidant systems were able to protect the cells against the injuries of reactive oxygen species. This hypothesis was supported by the slow induction of CAT activity measured in stickleback after 7 days of exposure to $500 \mu \mathrm{g}$ Pcz/L. CAT is involved in $\mathrm{H}_{2} \mathrm{O}_{2}$ elimination ${ }^{[28]}$ and could eliminate the excess of this very toxic reactive oxygen species generated by GPx inhibition. Interestingly, responses of enzymatic and non-enzymatic antioxidants were rapid and transient, suggesting the implication of Pcz metabolisation and elimination mechanisms involving phase II biotransformation enzymes such as GST, induced after the first week of exposure.

\section{Implication for Environmental Biomonitoring}

This study provides several elements to assess exposure to Pcz and other imidazole fungicides using biochemical biomarkers in three-spined stickleback. EROD activity was characterized by a fast dose-dependent induction followed by an adaptation phenomenon. This biomarker could provide a valuable information on Pcz exposure immediately after the contamination but, if the time between contamination and sampling is increased, the Pcz exposure cannot be

detected. ${ }^{[29]}$ EROD activity is a well documented biomarker of exposure to dioxin-like compounds but, in the light of these results, it could not be considered as a valuable 
biomarker to assess the exposure to Pcz fungicide. Enzymatic and non-enzymatic antioxidant parameters exhibited fast and transient responses. Moreover, antioxidant responses were only observed for the high tested concentrations. Consequently, biomarkers linked to oxidative stress could not giv valuable parameters to assess the imidazole exposures. In this work, GST appears as a more promising biochemical marker of exposure to Pcz. Our results showed that this phase II biotransformation enzyme is characterized by a fast induction followed by a slow recovery. Also, GST could provide a quantitative and time-integrated estimate of levels of pollution during environmental monitoring. ${ }^{[29]}$ This conclusion confirms the results of previous study indicating that GST is a valuable biomarker of exposure to several phytopharmaceutical compounds in fish and particularly in three-spined stickleback. ${ }^{[12]}$

\section{CONCLUSION}

This study showed that waterborne exposure to environmental Pcz concentrations induced Phase I and Phase II biotransformation enzymes in stickleback. EROD activity was moderately induced in a transient manner suggesting an extensive metabolisation. GST exhibited a dose-dependent induction that was also observed after depuration in clean water and could be considered as a valuable biomarker to assess the exposure to this imidazole compound while this enzyme is able to reflect present and past exposure to Pcz. For the high concentrations tested, Pcz promoted an oxidative stress characterised by depletion of GSH and perturbation of antioxidant enzyme activities. The mechanism by which Pcz promoted oxidative stress in fish is not fully understood but our results indicate that it is probably similar to the mecanism of other imidazole fungicides.

\section{ACKNOWLEDGMENTS}


We thank J. Sabarly for reviewing this manuscript. This work was supported by the French Ministry of Ecology and Sustainable Development (Budget Civil de la Recherche et du Développement AP-2004).

\section{REFERENCES}

[1] Zarn, J.A.; Brüschweiler, B.J.; Schlatter, J.R. Azole fungicides affect mammalian steroidogenesis by inhibiting sterol $14 \alpha$-demethylase and aromatase. Environ. Health Perspect. 2003, 111, 255-261.

[2] DIREN Ile de France "Info Phytos nº," 2005.

[3] DEFRA " The Government's Strategic Review of diffuse water pollution from agriculture in England - Paper 1: Agriculture and water: a diffuse pollution review," 2002.

[4] Larsen, J.; Sørensen, I. The effect of esfenvalerate and prochloraz on amphibians with special reference to Xenopus laevis and Bombina bombina. Pest. Res. 2004, 83, 1-68.

[5] Bach, J.; Snegaroff, J. Effects of the fungicide prochloraz on xenobiotic metabolism in rainbow trout : in vivo induction. Xenobiotica. 1989, 19, 1-9.

[6] Sturm, A.; Cravedi, J.P.; Perdu, E.; Baradat, M.; Segner, H. Effects of prochloraz and nonylphenol diethoxylate on hepatic biotransformation enzymes in trout: a comparative in vitro/in vivo-assessment using cultured hepatocytes. Aquat. Toxicol. 2001, 53, 229-245. [7] Ankley, G.T.; Jensen, K.M.; Durhan, E.J.; Makynen, E.A.; Butterworth, B.C.; Kahl, M.D.; Villeneuve, D.L.; Linnum, A.; Gray, L.E.; Cardon, M.; Wilson, V.S. Effects of two fungicides with multiple modes of action on reproductive endocrine function in the fathead minnow (Pimephales promelas). Toxicol. Sci. 2005, 86, 300-308. 
[8] Berhane, K.; Widersten, M.; Engstrom, A.; Kozarich, J.; Mannervik, B. Detoxication of base propenals and other $\alpha, \beta$-unsaturated aldehyde products of radical reactions and lipid peroxidation by human glutathione transferases. P. Natl. Acad. Sci. USA. 1994, 91, 14801484.

[9] Van der Oost, R.; Beyerb, J.; Vermeulen, N. Fish bioaccumulation and biomarkers in environmental risk assessment: a review. Environ. Toxicol. Pharmacol. 2003, 13, 57-149. [10] Sanchez, W.; Palluel, O.; Meunier, L.; Coquery, M.; Porcher, J.M.; Aït-Aïssa, S. Copperinduced oxidative stress in three-spined stickleback: relationship with hepatic metal levels. Environ. Toxicol. Pharmacol. 2005, 19, 177-183.

[11] Sturm, A.; Wogram, J.; Segner, H.; Liess, M. Different sensitivity to organophosphates of acetylcholinesterase and butyrylcholinesterase from three-spined stickleback (Gasterosteus aculeatus): application in biomonitoring. Environ. Toxicol. Chem. 2000, 19, 1607-1615.

[12] Sanchez, W.; Palluel, O.; Lagadic, L.; Aït-Aïssa, S.; Porcher, J.M. Biochemical effects of nonylphenol polyethoxylate adjuvant, Diquat herbicide and their mixture on the three-spined stickleback (Gasterosteus aculeatus L.). Mar. Environ. Res. 2006, 62, S29-S33. [13] Holm, G.; Norrgren, L.; Andersson, T.; Thuren, A. Effects of exposure to food contaminated with PBDE, PCN or PCB on reproduction, liver morphology and cytochrome P450 activity in the three-spined stickleback, Gasterosteus aculeatus. Aquat. Toxicol. 1993, $27,33-50$.

[14] Katsiadaki, I.; Scott, A.P.; Hurst, M.R.; Matthiessen, P.; Mayer, I. Detection of environmental androgens: a novel method based on enzyme-linked immunosorbent assay of spiggin, the stickleback (Gasterosteus aculeatus) glue protein. Environ. Toxicol. Chem. 2002, 21, 1946-1954. 
[15] Pottinger, T.G.; Carrick, T.R.; Yeomans, W.E. The three-spined stickleback as an environmental sentinel: effects of stressors on whole-body physiological indices. J. Fish Biol. 2002, 61, 207-229.

[16] Sanchez, W.; Aït-Aïssa, S.; Palluel, O.; Ditche, J.M.; Porcher, J.M. Preliminary investigation of multi-biomarker responses in three-spined stickleback (Gasterosteus aculeatus L.) sampled in contaminated streams. Ecotoxicology. 2007, 16, 279-287. [17] Bradford, M.M. A rapid sensitive method for the quantitation of microgram quantities of protein utilizing the principle of protein-dye binding. Anal. Biochem. 1976, 72, 248-254.

[18] Holm, G.; Lundström, J.; Andersson, T.; Norrgren, L. Influences of halogenated organic substances on ovarian development and hepatic EROD activity in the thrre-spined stickleback, Gasterosteus aculeatus, and rainbow trout, Oncorhynchus mykiss. Aquat. Toxicol. 1994, 29, 241-256.

[19] Flammarion, P.; Fortier, V.; Migeon, B.; Morfin, P.; Garric, J. Cytochrome P450 1A induction in gudgeon Gobio gobio : laboratory and field studies. Biomarkers. 1999, 4, 59-71. [20] Haasch, M.L.; Quardokus, E.M.; Sutherland, L.A.; Goodrich, M.S.; Prince, R.; Cooper, K.R.; Lech, J.J. CYP1A1 protein and mRNA in teleosts as an environmental bioindicator: laboratory and environmental studies. Mar. Environ. Res. 1992, 34, 139-145. [21] Navas, J.M.; Chana, A.; Herradon, B.; Segner, H. Induction of CYP1A by the Nimidazole derivative, 1-benzylimidazole. Environ. Toxicol. Chem. 2003, 22, 830-836. [22] Navas, J.M.; Chana, A.; Herradon, B.; Segner, H. Induction of cytochrome P4501A (CYP1A) by clotrimazole, a non-planar aromatic compound. Computational studies on structural features of clotrimazole and related imidazole derivatives. Life Sci. 2004, 76, 699714. 
[23] Babin, M.; Casado, S.; Chana, A.; Herradon, B.; Segner, H.; Tarazona, J.V.; Navas, J.M. Cytochrome P4501A induction caused by the imidazole derivative prochloraz in a rainbow trout cell line. Toxicol. in Vitro. 2005, 19, 899-902.

[24] Cravedi, J.P.; Boudry, G.; Baradat, M.; Rao, D.; Debrauwer, L. Metabolic fate of 2,4dichloroaniline, prochloraz and nonylphenol diethoxylate in rainbow trout: a comparative in vivo/in vitro approach. Aquat. Toxicol. 2001, 53, 159-172.

[25] Sanchez, W.; Palluel, O.; Cravedi, J.P.; Lagadic, L.; Porcher, J.M. Biochemical effects of nonylphenol polyethoxylate adjuvant and adjuvant-herbicide mistures on three-spined stickleback (Gasterosteus aculeatus L.), Proceeding of 13th international symposium Pollutant Responses in Marine Organisms, Alessandria, Italy, 2005, 93.

[26] Halliwell, B.; Gutteridge, J.M.C., Eds.; Free radicals in biology and medicine; $3^{\text {th }}$ ed.; Oxford University Press, 1999.

[27] Trivedi, V.; Chand, P.; Srivastava, K.; Puri, S.K.; Maulik, P.R.; Bandyopadhyay, U. Clotrimazole inhibits hemoperoxidase of Plasmodium falciparum and induces oxidative stress: proposed antimalarial mechanism of clotrimazole. J. Biol. Chem. 2005, 280, 4112941136.

[28] Knorpp, T.; Robinson, S.R.; Crack, P.J.; Dringen, R. Glutathione peroxidase-1 contributes to the protection of glutamine synthetase in astrocytes during oxidative stress. J. Neural Transm. 2006, 113, 1145-1155.

[29] Matés, J.M. Effects of antioxidant enzymes in the molecular control of reactive oxygen species toxicology. Toxicology. 2000, 153, 83-104.

[30] Wu, R.S.S.; Siu, W.H.L.; Shin, P.K.S. Induction, adaptation and recovery of biological responses: Implications for environmental monitoring. Mar. Poll. Bull. 2005, 51, 623-634. 


\section{FIGURE CAPTIONS}

Figure 1. Effect of 96 hours $\beta$-naphtoflavone treatment on hepatic EROD activity. Data represent mean $\pm \mathrm{SD}$ of the measurements on ten fish per group. * indicates group statistically different from control $(\mathrm{P}<0.05)$.

Figure 2. Effect of prochloraz 21 days treatment on biotransformation enzyme activities : EROD (A) and GST (B). Data represent mean \pm SD of the measurements on ten fish per group. For a same exposure concentration, group annotated with a same letter are not statistically different $(\mathrm{P}<0.05) . *$ indicates group statistically different from control $(\mathrm{P}<0.05)$. 


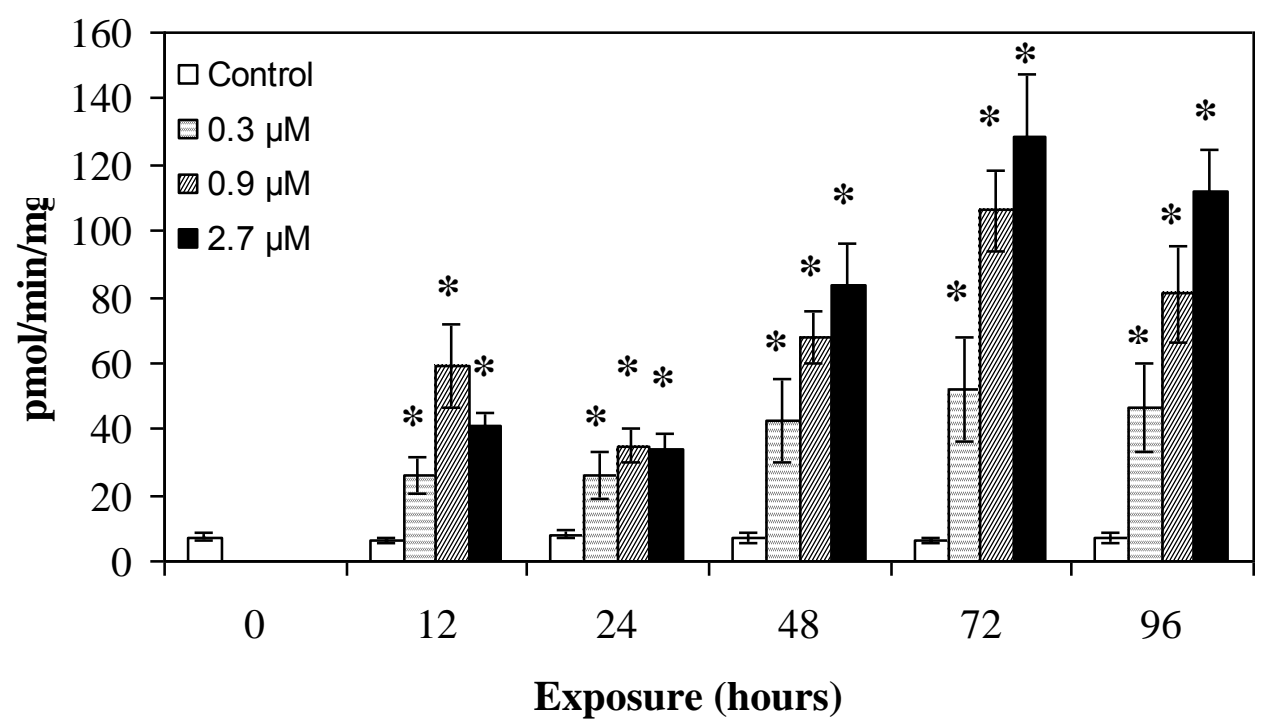

Fig. 1 

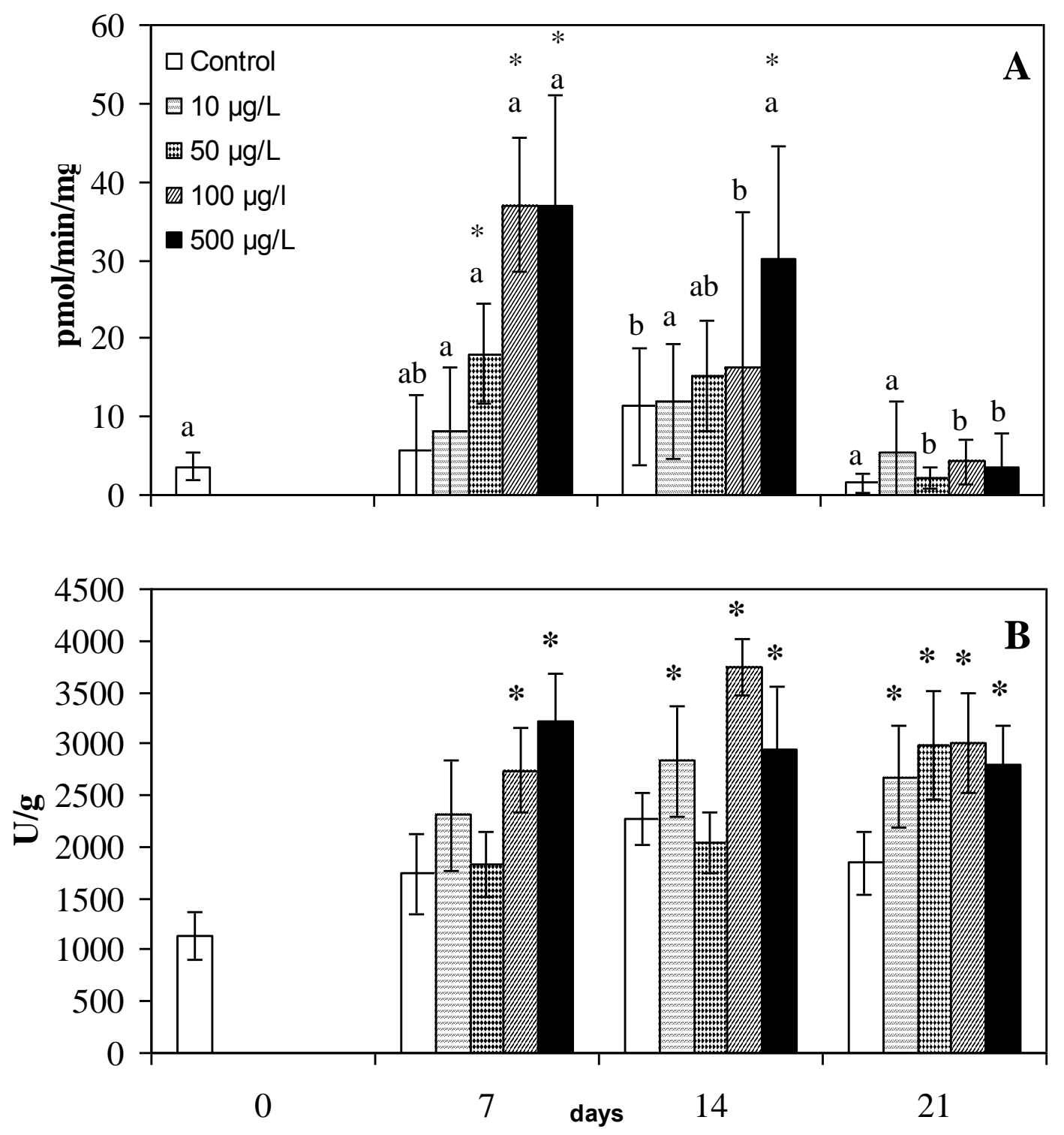

Fig. 2 
Table 1. Effect of 7 days prochloraz treatment on hepatic antioxidant parameters and TBARS content. Data represents mean \pm SD of the measurements on ten fish per group except for GPx where males and females have been separated. The number of fish is indicated between brackets. $(*)$ statistically different from control $(\mathrm{P}<0.05)$.

\begin{tabular}{|c|c|c|c|c|c|}
\hline & \multirow[b]{2}{*}{ Control } & \multicolumn{4}{|c|}{ Prochloraz $(\mu \mathrm{g} / \mathrm{L})$} \\
\hline & & 10 & 50 & 100 & 500 \\
\hline $\begin{array}{l}\text { Male GPx } \\
\text { (U/g prot.) }\end{array}$ & $51 \pm 4$ & $63 \pm 6$ & (1) & (1) & (1) \\
\hline $\begin{array}{l}\text { Female GPx } \\
\text { (U/g prot.) }\end{array}$ & $152 \pm 57$ & $138 \pm 53$ & $128 \pm 33$ & $84 \pm 32^{*}$ & $83 \pm 26^{*}$ \\
\hline $\begin{array}{l}\text { CAT } \\
\text { (U/g prot.) }\end{array}$ & $253 \pm 82$ & $374 \pm 108$ & $205 \pm 98$ & $412 \pm 115$ & $565 \pm 80^{*}$ \\
\hline $\begin{array}{l}\text { GSH } \\
\text { ( } \mu \mathrm{mol} / \mathrm{g} \text { prot.) }\end{array}$ & $7.6 \pm 4.1$ & $5.2 \pm 1.8$ & $3.5 \pm 2.5$ & $2.7 \pm 2.0^{*}$ & $1.2 \pm 1.0^{*}$ \\
\hline $\begin{array}{l}\text { TBARS } \\
\text { (nmol/g prot.) }\end{array}$ & $16.1 \pm 7.5$ & $15.4 \pm 10.2$ & $16.1 \pm 5.5$ & $22.1 \pm 21.1$ & $20.6 \pm 15.3$ \\
\hline
\end{tabular}

